DUBOVYK Tatiana,

DSc (Economics), Professor of Department of journalism and advertising

Kyiv National University of Trade and Economics Kyoto str., 19, Kyiv, 02156, Ukraine

E-mail: tatianavdubovik@gmail.com ORCID: https://orcid.org/0000-0001-9223-4629
BUCHATSKA Iryna,

$\mathrm{PhD}$ (Economics), Associate Professor of Department of journalism and advertising

Kyiv National University of Trade and Economics Kyoto str., 19, Kyiv, 02156, Ukraine

E-mail: irabuchatska@ukr.net ORCID: https://orcid.org/0000-0003-2413-7370

SAVCHUK Anastasiia,

$\mathrm{PhD}$ (Economics), Associate Professor of Department of journalism and advertising Kyiv National University of Trade and Economics

Kyoto str., 19, Kyiv, 02156, Ukraine

E-mail: aastsavchuk2016@gmail.com

ORCID: https://orcid.org/0000-0002-6960-6452

\title{
INFORMATION CYCLE OF STRATEGIC MARKETING
}

The article analyzes the peculiarities of information support system for strategic marketing decision making. According to the survey of trade enterprises management personnel, there is a discrepancy between the information need and its use. The importance of developing strategic marketing information support system is substantiated. The information cycle of strategic marketing of trade enterprises is considered. Within the information cycle of strategic marketing of trade enterprises the levels of development of information support are defined, namely: operational, consolidation, integration, optimization, innovative.

Keywords: information cycle, information supply of strategic marketing, information needs, marketing strategy, marketing information.

Дубовик Т., Бучацкая И., Савчук А. Информационный цикл стратегического маркетинга. Проанализированы особенности информационного обеспечения принятия стратегических маркетинговых решений. По результатам опроса управленческого персонала предприятий торговли определено несоответствие между потребностями в информации и ее использованием. Обоснована значимость развития информационного обеспечения стратегического маркетинга. Рассмотрен информационный иикл стратегического маркетинга предприятий торговли. В рамках информационного иикла определены уровни развития информационного обеспечения, а именно: оперативный, консолидаџии, интеграџии, оптимизаџчи, инноваџионный.

Ключевые слова: информационный цикл, информационное обеспечение стратегического маркетинга, информационные потребности, маркетинговая стратегия, маркетинговая информация.

Background. The strategic marketing information supply operation is permanent; the collection, analysis and use of information are continuous, due to the dynamic changes occurring in the enterprise environment and possible changes in the strategic objectives of the enterprise. The strategic marketing information cycle involves defining information needs and requests

ㄷ Dubovyk T., Buchatska I., Savchuk A., 2019 
based on strategic marketing objectives and assessing the level of satisfaction of the information needs of its recipients. Information interests can be expressed through the specific objectives of the enterprise: economic, marketing, socio-ethical, technological, organizational. Economic and marketing goals are dominant for retail enterprises. Information interests provide the definition of information purpose, taking into account the economic interests and marketing objectives of trade enterprises. Economic interests of trade enterprises emerge from the necessity of continuous improvement of financial and economic conditions and are determined by quantitative and qualitative indicators: volume of goods turnover, profitability, income level, etc. Quantitative indicators characterize the enterprise results, which can be measured by calculation of data - these are reliable facts, the main characteristics of which are truthfulness and objectivity. Qualitative indicators characterize the level and characteristics of the processes development, characteristics of phenomena that are difficult to quantify and compare, since they reflect the long-term effect and are based on experience. In our opinion, within the information cycle of strategic marketing, it is expedient to consider the information request as the information requirements addressed to the enterprise information system for the implementation of strategic marketing tasks.

An important condition for correct information requests production is the knowledge about the essence and purpose of information. Information interests are determined by speed and quality indicators of managerial decisions, which is associated with the usage of different types of information and methods of analyzing it. It is important to consider information need, interest and requests as the basis for further collection, analysis and interpretation of the necessary marketing information. Thus, strategy formation is not the result of a strategy workshop or the application of a strategy method and extended analyses, or a formalized concept of an entrepreneurial vision, it is associated with permanent searching and interpreting information by managerial personnel or entrepreneur [1, p. 362]. Marketing information system can support managers in their marketing decision making by providing them with internal linking and operational integration between departments or business units. It can also increase the ability to respond to the Organizational dynamic system environment, allows the most efficient handling, and organize and store data [2, p. 331].

Using informal information, from personnel networks of the business entity, may assure a faster response to new events. The ability to learn from the experiences of employees at all level is important for strategies to emerge and effective strategic decisions making from a communicative interaction among relevant organizational members [3; 4]. Employees may have a very active role in the strategy formation process encouraged by communication with the small business manager [5]. The external environment moderates the strategy formation performance relationship and expects that dynamic industries offers opportunities that can exploited more easily by emergent 
strategists while in stable industries a planned strategy is required considering in advance the actions of various factors determining competition [1]. While some stages of strategic marketing process repeated, appears holistic judgment which is based on the previous experience of the decision maker, and is analogous to "making holistic associations" [6, p. 42]. Faced with higher storage costs and burgeoning data growth, the concept of information life cycle management has emerged to help management understand their information needs and to structure their storage spending in a way that meets those needs [7]. Automated decision technologies affect organizational performance by facilitating routine tasks [8, p. 30]. The automation of routine and often tedious tasks allows a decision maker to explore a problem more thoroughly $[9$, p. 723].

It is important to determine information needed for managerial decision making. Information needs are considered as a need for information or activities, eliminating the imbalance between the present and desired state of the subject information environment [10]. Any information needed in the management process is a formal description of the task and ways of its successful solution, as well as recommendations for the result application in different situations [11, p. 41] The reliability of information refers to the fact that this information must be accurate and precise. Some researchers consider the information need as a form of manager's attitude to the information needed to solve a specific task. The information needs formation is significantly influenced by the type of management activity and the peculiarities of the functions performed [12]. It should be noted, that information needs are divided into conscious and unconscious. Information interest is a conscious information need, which is an incentive for searching and using of information resources. Information interests of trade enterprises are strongly connected with their economic and marketing objectives. Investigation of information needs and requests is an important task for managerial personnel of trade enterprises.

Analysis of recent research and publications. Different scientists have studied the role of information processing and economic environment investigation for marketing strategy formation. Some authors investigated the necessity of regular monitoring of the functioning process of the marketing information management system in order to find out whether it corresponds to general aims and tasks of the enterprise [13, p. 53]. Marketing information is regarded as one of the main factors for holding leading positions in the market segment of the enterprises.

The information systems development and implantation should start from clarifying its strategic, tactical and operational objectives (long, medium and short term) [14].

The relationship between systematic collection and analysis of publicly available information about consumers, competitors, and developments in the marketplace and gaining competitive advantage was investigated by scientists. The results of the analysis showed that there is a relationship 
between the major components of marketing information system like internal records, marketing research, and marketing intelligence towards achieving a competitive advantage. Therefore, marketing intelligence explores the usefulness of the use of information technology in achieving competitive advantage [15].

Some authors have also suggested that there is a significant relationship between all the sub-constructs of marketing intelligence, such as internal records, competitors' sales data, marketplace opportunity, competitive threat and competitive risk to business competitive advantage. Therefore, above average returns can be maintained if a company gains business competitive advantage in the market over time, and all these are attributed to the amount of market information and intelligence a company can gather, store and utilize to the best of its advantage. Such information and marketing intelligence enable enterprises successfully acquire more profit, expand its branch network, perform better than its rivals in the market and increase its competitive advantage [16, p. 53].

A large number of existing studies in the broader literature have examined seeking, collection and use of information, as well as information needs, interests and queries, but they were not considered within the company's information cycle.

The aim of the article is to investigate the information needs of managerial personnel of enterprises and to develop strategic marketing information cycle.

Materials and methods. For the purpose of the research, we applied the methods of analysis and synthesis in order to study the peculiarities of strategic marketing information support system, questionnaires to investigate the selection of information sources used by consumers and identify the level of information needs satisfaction of management personnel.

Results. Thus, the study of information needs and requests of management personnel in accordance with the target audience of enterprises is a matter of urgency (table 1). First of all, we investigated with questionnaire by "Google Forms" regarding the influence of information on customers buying decisions. Due to results of this investigation, the Internet posts (experts' reviews, blogs, and forums), online-stores, web-sites, comparison sites and social networks information proved to be the most significant of all the information sources, which influence the decisions of customers - to buy or not to buy goods in stores.

According to table 1, the main source of information about the company for most consumers is the feedback from experts, bloggers and the information in social networks and on the site of the company. Thus, tracking consumer information from online resources can be used by retail enterprise when strategic decision making about communication and price policy and should be taken into account while marketing strategy development. To develop recommendations about information cycle, we investigated the level of information in the course of developing and implementing a marketing strategy on retail enterprises. 
The sources of information which influence

Table 1 the respondents buying decision in stores, $\%$

\begin{tabular}{|l|c|c|c|c|c|}
\hline \multirow{2}{*}{\multicolumn{1}{|c|}{ Information sources }} & \multicolumn{5}{c|}{ Age of respondents } \\
\cline { 2 - 6 } & $16-19$ & $20-29$ & $30-39$ & $40-55$ & $\begin{array}{c}56 \text { and } \\
\text { more }\end{array}$ \\
\hline Experts and bloggers messages & 54.6 & 69.6 & 42.6 & 53.1 & 37.5 \\
\hline Relatives, friends, colleagues referrals (word of mouth) & 21.9 & 21.6 & 17.6 & 18.8 & 43.8 \\
\hline Corporate web-site (company, brand or product) & 31.9 & 36.8 & 30.6 & 46.9 & 75.0 \\
\hline Price comparison web-sites & 45.4 & 52.8 & 40.7 & 65.6 & 37.5 \\
\hline Advertising background in stores & 7.6 & 6.4 & 10.2 & 21.9 & 18.8 \\
\hline Online news sources & 10.9 & 14.4 & 13.0 & 40.6 & 56.3 \\
\hline Salesman recommendations & 1.7 & 2.4 & 4.6 & 12.5 & 12.5 \\
\hline Printed advertising & 10.1 & 7.2 & 15.7 & 15.6 & 37.5 \\
\hline Enterprise information in social networks & 46.2 & 36.8 & 32.4 & 53.1 & 43.8 \\
\hline TV and radio advertising & 4.2 & 8.8 & 16.7 & 25.0 & 56.3 \\
\hline Customers information on forums & 32.8 & 34.4 & 25.9 & 34.4 & 31.3 \\
\hline Online advertising in search engines & 37.8 & 28.8 & 20.4 & 28.1 & 25.0 \\
\hline Online advertising in social networks & 23.5 & 27.2 & 25.0 & 25.0 & 50.0 \\
\hline Online-stores web sites & 42.9 & 38.4 & 29.6 & 59.4 & 37.5 \\
\hline Printed chapbooks/catalogues & 3.4 & 5.6 & 10.2 & 15.6 & 12.5 \\
\hline E-mail advertising dispatch & 16.0 & 15.2 & 13.0 & 25.0 & 31.3 \\
\hline Manufacturers' online-stores & 10.9 & 14.4 & 14.8 & 59.4 & 50.0 \\
\hline
\end{tabular}

Source: authors investigations, samples - 400, statistical error - 0.945 doesn't exceed $0.055(5.5 \%)$.

The authors conducted a survey of directors, deputy managers, marketers and commercial directors of trade enterprises in Ukraine. Sizes of investigated enterprises are large and medium, according to quantity of employees and annual income. As the research showed, despite the availability of information needs, the level of information use when performing strategic marketing tasks varies. The lowest level of information usage is observed in the study of the influence of the macro environment, the state and trends in the market, consumption trends, forecasting the future development of the enterprise and monitoring the efficiency of marketing strategy. The obtained results prove the need to develop recommendations for the external information collection, analysis and evaluation of the marketing strategy efficiency (table 2).

The complexity of gathering information about the environment may be due to the limited access to information resources that characterize the activities of competitors and the lack of market research opportunities. Insufficient information in the study of the marketing strategy effectiveness depends on the accuracy of the selected indicators for its evaluation, as well as the possibility of identifying the causes that affect the obtaining of such results. Forecasting the development of an enterprise is complicated by the volatility and dynamic changes of the environment at micro and macro levels. 
Level of information needs for the implementation of strategic marketing tasks by retail enterprises, $\%$

\begin{tabular}{|l|c|c|c|c|}
\hline \multirow{2}{*}{\multicolumn{1}{|c|}{ Type of information }} & \multicolumn{2}{c|}{ Need } & \multicolumn{2}{c|}{ Use } \\
\cline { 2 - 5 } & $\begin{array}{c}\text { Large } \\
\text { enterprises }\end{array}$ & $\begin{array}{c}\text { Medium } \\
\text { enterprises }\end{array}$ & $\begin{array}{c}\text { Large } \\
\text { enterprises }\end{array}$ & $\begin{array}{c}\text { Medium } \\
\text { enterprises }\end{array}$ \\
\hline Condition and prospects of economic development & 100.0 & 95.1 & 61.0 & 76.0 \\
\hline $\begin{array}{l}\text { Macroeconomic factors influence on the imple- } \\
\text { mentation of the enterprise marketing strategy }\end{array}$ & 100.0 & 92.2 & 81.0 & 48.0 \\
\hline Purchasing power of the population & 100.0 & 98.1 & 94.0 & 90.0 \\
\hline Market conditions and trends & 90.3 & 84.5 & 71.0 & 52.4 \\
\hline Competitors research & 100.0 & 95.1 & 84.0 & 54.4 \\
\hline Current and future needs of consumers & 100.0 & 75.7 & 87.0 & 84.5 \\
\hline Trends in consumption & 80.6 & 85.4 & 55.0 & 35.9 \\
\hline $\begin{array}{l}\text { Projections of the enterprise development taking } \\
\text { into account internal possibilities and influence } \\
\text { of external factors }\end{array}$ & 90.3 & 75.7 & 64.5 & 34.0 \\
\hline $\begin{array}{l}\text { The effectiveness of the marketing strategy } \\
\text { of the enterprise }\end{array}$ & 100.0 & 86.4 & 83.9 & 47.6 \\
\hline
\end{tabular}

Source: authors investigations.

Among the areas for improving the information provision of strategic marketing in order to increase the level of information security, it is appropriate to note the application of various methods of analysis and forecasting, as well as the use of information and communication technologies. It is important to take into account the previous level of information security with its further collection, as the development of information provision for strategic marketing has an iterative nature. Iterative models were considered earlier by scientists for software engineering [17]. This model constructs a partial implementation of a total system. Then, it slowly adds increased functionality. Therefore, each subsequent release will add a function to the previous one until all designed functionalities are implemented [18, p. 99]. The information cycle of strategic marketing of retail companies is considered as a period of information resources usage at each stage of strategic marketing management: from the emergence and awareness of information needs, the formation of information interests and requests by the management of the company to exercise control over its implementation, on iterative basis of this process. The type of information, the frequency of its collection, and the source may be different, but some of the steps involved in filling the strategic marketing data base are repeated within the strategic marketing information cycle (figure).

We distinguish the following levels of development of information support system within the strategic marketing information cycle of trade enterprises: operational, consolidation, integration, optimization, innovation.

Based on the Iterative Development approach, the project, in our case marketing strategy, is divided into small parts. This allows demonstrating results earlier on in the process and obtaining valuable feedback from 60 
system users. Often, each iteration is actually a process with the feedback from one phase providing vital information for the design of the next phase. The level of information supply development is connected with the necessity of using different information at each of its stages, depending on the level of information support from the existing information needs and their changes. The emergence of information needs with developing new marketing strategies involves the beginning of a new information cycle, taking into account the current base of strategic marketing data.

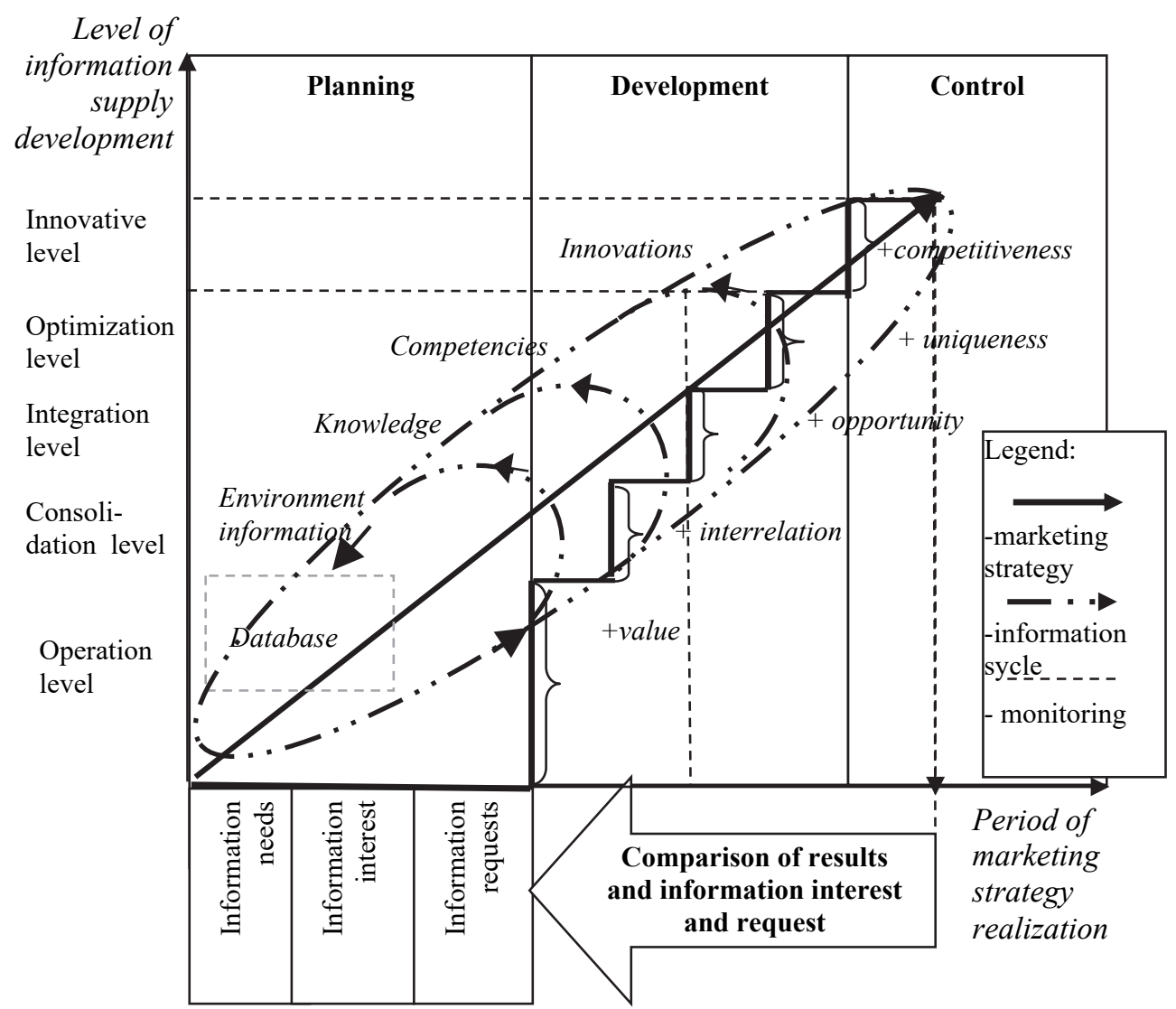

\section{Strategic marketing information cycle}

The operational level involves the creation of database about the enterprises internal environment, the accumulation of the enterprise performance indicators values used to assess the level and nature of enterprise development.

At the consolidation level, information is collected and marketing research that allows obtaining initial data about the external environment of the enterprise can be conducted. At this level the relationship and trends of changes in the external and internal environment of the enterprise are determined.

The integration level involves analytical processing of information with expert methods and intelligent analysis of data usage. The main task of this level is to convert the collected information into knowledge. 
The optimization level involves the effective usage of knowledge gained during the previous levels, when making strategic marketing decisions.

The innovative level involves usage of modern information and communication technologies for large volumes of data analytical processing and the software and automated decision technologies, which provide the ability to forecast the enterprise development in the long-term period. It should be noted that the achievement of the innovative level is desirable, but not all enterprises achieve it.

Information technology on retail enterprises provides opportunities for collecting information from different channels of sales, monitoring and evaluation of consumer preferences of different segments, analysis of large volumes of data, but their introduction requires the attraction of significant financial resources, technical readiness of the enterprise, and relevant skills of its staff. The achievement of a certain level of development of the information support of the trading company in fulfilling the objectives of strategic marketing depends on the intensity of various resources use. Using the model of strategic marketing information cycle allows us to choose further directions of information security improvement on the basis of determining the existing level of information.

Conclusion. Information needs of managers during the implementtation of strategic marketing tasks form information interests that can be represented by the objectives of the enterprise. Improving the process of meeting the information needs of individuals who make strategic marketing decisions involves consideration of the information cycle of strategic marketing, which is the basis of the formation and development of information provision. Identifying information needs at different stages of strategic marketing and developing recommendations for providing the necessary data for their satisfaction will allow the adoption of reasonable management decisions. Increasing the efficiency of marketing strategy implementation is possible through monitoring changes in enterprise performance before, during and after the implementation of each strategy.

This research provides data about the information usage at different stages of strategic marketing process. Investigation of the information needs level for the implementation of strategic marketing tasks by retail enterprises, showed that there is discrepancy between the need and usage of information.

These findings should be viewed in light of some limitations. The sample set of enterprises in this study can be wider. Small enterprises and enterprises of other industries might be investigated too.

Further research about the impact of using information obtained on the speed, accuracy and efficiency of adopting relevant strategic decisions can increase their effectiveness in the future. However, theoretical conclusions require empirical studies. It is advisable to identify several ways of research. Firstly, the strategic marketing information cycle was considered, albeit in a simplified form, and in the future it would be necessary to analyze the synergy effect for various strategic marketing programs, taking into account the rotation of some processes. It is advisable to consider separately the 
extent of the impact of Internet sources on the information cycle and peculiarities of information needs on other types of enterprises. Research on these practical issues will allow empirically confirm the theoretical conclusions regarding the use of the information cycle of retail enterprises.

\section{REFERENCES}

1. Leitner, Karl-Heinz (2014). Strategy formation in the innovation and market domain: emergent or deliberate? Journal of Strategy and Management. (Vol. 7). Issue 4. (pp. 354-375) [in English].

2. Freihat 'Mohammadsaid' Sultan (2012). The role of marketing information system in marketing decision-making in Jordanian shareholding medicines production. International Journal of Recent Research and Applied Studies. 11 (2), 326-336 [in English].

3. Noe, R. A., Hollenbeck, J. R., Gerhart, B., \& Wright, P. M. (2003). Human Resource Management: Gaining a Competitive Advantage. McGraw-Hill, NY [in English].

4. Carr, A., Durant, R., \& Dowens, A. (2004). Emergent strategy development, abduction, and pragmatism: new lessons for corporations. Human Systems Management. (Vol. 23), 2. 79-91 [in English].

5. Luke, B., \& Verreynne, M. (2006). Exploring strategic entrepreneurship in the public sector. Qualitative Research in Accounting \& Management. (Vol. 3). Issue 1. (pp.4-26) [in English].

6. Dane, E., \& Pratt, M. (2007). Exploring Intuition and Its Role in managerial Decision Making. The Academy of Management Review, 32, 33-54 [in English].

7. Tallon, P. (2007). Richard Scannell. Information lifecycle management. Communications of the ACM. (Vol. 50), 11, 52-59 [in English].

8. Davenport, T., \& Harris, J. (2010). Leading the way towards better business insights. Strategic HR Review. (Vol. 9). Issue 4. (pp. 28-33) [in English].

9. Pick, R. A. (2008). Benefits of decision support systems. Handbook on Decision Support Systems, 1, 719-730 [in English].

10. Starostina, A. (2005). Industrial Marketing: Theory, World Care, Ukrainian Practice. Kyiv: Znannia [in English].

11. Davydova, I. (2015). Patterns of managers information needs in the information management system. Herald of the book chamber, 2, 39-42 [in English].

12. Korostelev, A. (2012). Analytical activity: assessment of the level of information support. Vecto rscience of TSU, 3 (10), 36-42 [in English].

13. Ashmarina, S., \& Zotova, A. (2016). The system of marketing information management: development, assessment, improvement. Economic Annals-XXI, 160 (7-8), 51-55 [in English].

14. Mishulin, G. M., Molchan, A., Biryukov, A., \& Haradzhyan, L. (2016). Integrated Marketing Information and Communication System: New Quality of the Communication Interaction. International Review of Management and Marketing, 6, 7-14 [in English].

15. Alhadid, Y., Al-Zu'bi, H., \& Samer, B. (2015). The relationship between marketing information system and gaining competitive advantage in the banking sector in Jordan. European Journal of Scientific Research, 128(1), 35-44 [in English].

16. Ade, L., Awoniyi, M., \& Tubosun, A. I. (2017). The Influence of Marketing Intelligence on Business Competitive Advantage. Journal of Competitiveness., (Vol. 9). Issue 1. (pp. 51-61) [in English]. 
17. Sommerville, I. (2004). Software Engineering. Addison Wesley. 7th ed. [in English]. 18. Munassar, N. \& Govardhan, A. (2010). A Comparison Between Five Models Of Software Engineering. International Journal of Computer Science Issues. (Vol. 7). Issue 5. (pp. 94-101) [in English].

The article submitted to editor's office on 25.11.2019.

\section{Дубовик Т., Бучацька І., Савчук А. Інформаційний цикл стратегічного маркетингу. \\ Постановка проблеми. Удосконалення процесу задоволення інформаційних потреб} осіб, які приймають стратегічні маркетингові рішення, передбачає розгляд інформаційного ииклу стратегічного маркетингу, щзо є основою формування та розвитку інформачійного забезпечення. Саме виявлення інформачійних потреб на різних етапах стратегічного маркетингу та формулювання рекомендачій щьодо надання необхідних даних для їх задоволення дадуть змогу приймати обгрунтовані управлінські рімення.

Аналіз останніх досліджень $і$ публікацій показав, щзо інформаційне забезпечення суттєво впливає на досягнення конкурентних переваг та розвиток підприємств у стратегічній перспективі.

Мета статті - вивчення рівня інформачійних потреб управлінського персоналу підприємств та розгляд інформаційного ичклу стратегічного маркетингу.

Матеріали та методи. Використано методи аналізу та синтезу для дослідження особливостей інформаційного забезпечення стратегічного маркетингу, анкетування - для дослідження джерел інформачії, щз використовуються спожсивачами, та визначення рівня задоволеності інформаційних потреб керівного персоналу.

Результати дослідження. За даними опитування управлінського персоналу підприємств торгівлі визначено, ше існує невідповідність між потребами в інформації та їі використанням. Обтрунтовано необхідність врахування ииклічності розвитку інформаційного забезпечення, що пов'язано з потребою використання різної інформації на різних етапах стратегічного маркетингу, ї̈ накопичення та зміни інформаційного стану підприємства. 3 огляду на ие, розглянуто інформачійний ичикл стратегічного маркетингу як період використання інформаційних ресурсів на кожному з етапів управління стратегічним маркетингом: від виникнення й усвідомлення інформаційної потреби, формування інформаційного інтересу та інформаційного запиту керівництвом підприємства при визначенні мети розробки та вибору маркетингової стратегії підприємств торгівлі до контролю ї̈ реалізаиії. У межах інформаційного ичклу стратегічного маркетингу підприємств торгівлі розглянуто рівні розвитку інформаційного забезпечення, а саме: оперативний, консолідації, інтеграиї̈, оптимізачії, інновачійний.

Висновки. Використання моделі інформаційного ичиклу стратегічного маркетингу дає змогу обирати подальші напрямки вдосконалення інформаційного забезпечення. Підвищення ефективності реалізації маркетингової стратегії можливе завдяки моніторингу змін у діяльності підприємства до, під час та після реалізаиії стратегій.

Подальші дослідження впливу використання інформаиії, отриманої на швидкість, точність та ефективність прийняття відповідних стратегічних рішень, можуть підвищити їх ефективність у майбутньому. Однак теоретичні висновки потребують емпіричних досліджень. Дочільно визначити кілька способів дослідження. Передусім, інформаційний циикл стратегічного маркетингу розглядався у спрощеній формі, і надалі необхідно проаналізувати ефект синергії для різних стратегічних маркетингових програм з урахуванням ротації деяких процесів. Доцільно розглянути окремо ступінь впливу інтернет-джерел на інформачійний ичикл та особливості інформаційних потреб на інших видах підприємств. Дослідження ичих практичних питань нададуть можливість емпірично підтвердити теоретичні висновки щодо використання інформаційного ичиклу підприємств роздрібної торгівлі.

Ключові слова: інформаційний цикл, інформаційне забезпечення стратегічного маркетингу, інформаційні потреби, маркетингова стратегія, маркетингова інформація. 